\title{
TANTANGAN DAKWAH DI PERKEBUNAN KARET DAN KELAPA SAWIT TRANSMIGRAN SUMBER MAKMUR PALEMBANG
}

\author{
Mar'atus Sholehah \\ Mahasiswa Pascasarjana Komunikasi dan Penyiaran Islam UIN Walisongo \\ Zhumarzhu@yahoo.co.id
}

\begin{abstract}
$T$ he review of the challenges of da'wah in the Sumber Makmur Palembang rubber and oil palm plantation area has not been done much by the researchers. The focus of the problem to be explored is the response and the pioneering paradigm of the pioneers of the Sumber Makmur religion towards cultural and religious diversity, as well as how the da'wah strategies they have developed in maintaining inter-faith harmony. The data from the research show that the views and attitudes of the religious activists in Sumber Makmur towards cultural diversity and religion, generally refer to the respecting and respectful paradigm of respect. All Sumber Makmur villagers are very influential on the concept of preaching. To realize an effective Islamic da'wah strategy so that it can change the condition of the community. How can a dai adapt his da'wah method to the conditions of transmigrant village people who tend to accept surrender and be less communicative with others. The strategy of Islamic da'wah in transmigration areas must not be carried out by one institution, but must involve various parties. Obviously the government, da'wah bodies, Islamic organizations and the da'I themselves, should work together and work together in smoothing out da'wah activities. Da'wah in Transmigran village focuses on improving the economy, education, health, transportation facilities, and other facilities.
\end{abstract}

Keywords: Propagation, Plantation, Transmigran, Da'wah Strategy

\begin{abstract}
ABSTRAK
$\mathrm{T}$ injauan tantangan dakwah di daerah perkebunan karet dan kelapa sawit Sumber Makmur Palembang ini belum banyak dilakukan oleh para peneliti. Fokus masalah yang akan ditelaah adalah respon dan paradigma pelopor-pelopor agama Sumber Makmur terhadap keragaman budaya dan agama, serta bagaimana strategi dakwah yang mereka kembangkan dalam memelihara harmoni antar iman. Data hasil penelitian menunjukkan bahwa pandangan dan sikap tokoh agama di Sumber Makmur terhadap keberagaman budayadan agama, secara umum mengacu pada paradigma hormat mengormati dan saling menghargai. Seluruh masyarakat desa Sumber makmur sangat berpengaruh terhadap konsep berdakwah. Untuk mewujudkan strategi dakwah islamiyah yang efektif sehingga dapat merubah kondisi masyarakat tersebut. Bagaimana seorang dai dapat menyesuaikan metode dakwahnya dengan keadaan masyarakat desa transmigran yang cenderung menerima sikap pasrah dan kurang komunikatif dengan orang lain. Strategi dakwah Islam di kawasan transmigrasi tidak boleh dijalankan oleh satu institusi saja, tapi harus melibatkan berbagai pihak. Jelasnya pihak pemerintah, badan dakwah, organisasi Islam dan para da'i sendiri, semestinya bersipadu dan bekerja sama dalam melicinkan aktivitas dakwah. Dakwah di desa Transmigran fokus pada perbaikan ekonomi, pendidikan, kesihatan, sarana transfortasi, dan fasilitas lainnya.
\end{abstract}

Kata kunci: Dakwah, Perkebunan, Transmigran, Strategi Dakwah

$207 \mid \begin{aligned} & \text { Islamic Comunication Journal } \\ & \text { Volume 03, nomor 2, Juli-Desember } 2018\end{aligned}$ 


\section{PENDAHULUAN}

Program transmigrasi memegang peranan penting dalam pembangunan nasional. Kita ketahui bahwa program transmigrasi mampu meningkatkan kesejahteraan transmigran dan masyarakat sekitar, memperkokoh persatuan dan kesatuan bangsa dan mendukung pembangunan daerah. Indonesia adalah sedikit diantara Negara-negara di dunia yang memiliki Departemen Transmigrasi, suatu badan tingkat tinggi yang bertugas mendorong redistribusi penduduk didalam negeri (Said Rusli, 1981:150).

Transmigrasi ialah perpindahan, dalam hal ini memindahkan orang dari daerah yang padat ke daerah yang jarang penduduknya dalam batas Negara dalam rangka kebijaksanaan nasional untuk tercapainya penyebaran penduduk yang lebih seimbang (Heeren, 1979:6).

Menurut Peraturan Pemerintah Republik Indonesia No. 3 Tahun 2004 tentang Pelaksanaan ketransmigrasian menyatakan ketransmigrasian adalah segala sesuatu yang berkaitan dengan penyelenggaran transmigrasi, transmigrasi adalah perpindahan penduduk secara sukarela untuk meningkatkan kesejahteraan dan menetap di kawasan transmigrasi yang diselenggarakan oleh pemerintah (di unduh 14 februari 2018).

Dengan adanya transmigrasi otomatis membawa pengaruh baik berupa kehidupan sosial maupun kehidupan ekonomi, dalam hal ini transmigrasi sangat berperan untuk memperbaiki nasib kehidupan sosial ekonomi suatu kelompok Masyarakat, selain itu juga pencapaian penduduk yang seimbang merupakan tujuan utama baik bagi sebagian orang maupun penjabat pemerintahan dari program transmigrasi itu sendiri. Kehidupan sosial masyarakat sendiri terjadi karena adanya proses sosial, hal ini dikarenakan didalam masyarakat sering sekali terdapat perbedaan-perbedaan kebutuhan diantara warga atau golongan khusus suatu masyarakat yang diakibatkan oleh adanya proses sosial meliputi adat istiadat kebutuhan individu, ketegangan sosial yang muncul akibat adanya masyarakat yang menentang adat istiadat itu sendiri (Koentjaraningrat, 1997:185).

Transmigrasi adalah mati hidupnya kita, transmigrasi harus menjadi masalah nasional, gerakan nasional, gerakan masa rakyat dalam pengintegrasian antara pemerintah dan rakyak secara terorganisasi yang merupakan upaya peningkatan kemakmuan, kesejateraan serta persatuan dan kesatuan bangsa dengan perpindahan penduduk (Sardjadidjaja,2004 : 25-26).

Jika dilihat dari wilayah pembagunan yang ada di Sumatera Selatan, selaras dengan aspek yang terdapat dalam faktor ekonomi antara lain meliputi bumi, tenaga kerja, pembinaan dan distribusi maka penduduk transmigrasi khususnya Jawa dan Bali yang memiliki tenaga kerja kompeten dalam mengelolah lahan terutama lahan pertanian, selanjutnya dengan memindahkan penduduk tersebut ke daerah atau negara yang masih kekurangan tenaga kerja akan dapat menekan laju pertambahan penduduk (Alibasya,1980:19-21)

Sumatera Selatan adalah salahsatu provinsi di Indonesia yangterletak di bagian selatan pulau Sumatera, Ibu kota dari Provinsi Sumatera Selatan sendiri adalah Palembang. Secara geografis provinsi Sumatera Selatan berbatasan 
dengan provinsi Jambi diutara, provinsi kep. Bangka-Belitung di timur, provinsi Lampung diselatandan provinsi Bengkulu dibarat. Provinsi ini kaya akan sumber daya alam, seperti minyak bumi, gas alam dan batu bara. Selain itu ibu kotaprovinsi Sumatera Selatan, Kota Palembang sendiri telah terkenal sejak zaman dahulu karena menjadi pusat kerajaan Sriwijaya.

Daerah Nibung adalah daerah transmigarasi dari bergabai macam suku dan budaya yang multikultural karena di daerah Nibung sendiri terdiri dari 12 desa yang dihuni oleh masyarakat pendatang dan masyarakat asli Palembang. Desa Sumber Makmur terbentuk dari berbagai ragam kelompok suku, etnis, budaya, bahasa, agama dan lain-lain. Dengan keragaman tersebut maka Sumber Makmur dapat dikatakan sebagai desa yang "multikultural". Di sisi lain, kenyataan bahwa masyarakat Sumber Makmur yang multikultural tersebut dihadapkan pada kebutuhan yang mendesak, harus bertahan hidup dari minimnya pangan yang diberikan oleh pemerintah. Karena harus menunggu eman tahun kemudian baru bisa memanen karet dan sawit jatah dari transmigran itu sendiri. Mereka juga harus bisa beradaptasi dengan keadaan daerah yang blukal (masih banyak hutan) tidak seperti tempat asala mereka, beradaptasi dengan perbedaan bahasa, agama, dan ras.

Perbedaan budaya, bahasa, adat istiadat dalam hajatan, menambah kompleknya masalah di Desa Sumber Makmur. Karena awal datang ke Sumber Makmur itu merasa susah dalam berbahasa karena banyaknya perbedaan budaya. Dan itu menjadi masalah dalam pergerakan sosial dilingkungan sendiri. Akhirnya siapa yang berani, rajin dan mau belajar maka mereka yang bertahan. Lagi-lagi agama yang menjadi penengah semua umat yang ada di masyarakat sana, karena agama masuk dalam sosial masyarakat yang beda budaya.Agama bisa masuk dikalangan santri, Agama bisa masuk dari kalangan masyarakat kejawen, agama bisa masuk dikalangan petani, agama bisa masuk dikalangan anak-anak.

Untuk mengetahui secara luas tentang tema ini, penulis berusaha mengumpulkan penelitian-penelitian yang terkait dengan tema makalah, penelitian berhubungan dengan dakwah di perkebunan Transmigrasi yaitu: (1. Wulan, (2016), "Perkembangan kehidupan Sosial Ekonomi" adapun tujuan artikel ini adalah untuk mengetahui perkembangan kehidupan sosial masyarakat daerah transmigran di desa Karya Mulya kota Prabumulih. (2. Sumarni, (2017), "Sejarah Sosial Ekonomi Masyarakat Transmigrasi" Hasil artikel ini menunjukan bahwa masyarakat transmigrasi datang pada tahun 1967 - 1980. Tujuan masyarakat untuk ikut program transmigrasi karena faktor kemiskinan. (3. Siti Abir Wulandarli, (2016), “Kajian Komoditas Unggulan Sub-Sektor Perkebunan Di Provinsi Jambi" hasil dari artikelnya adalah berdasarkan data yang ada terlihat peningkatan luas lahan baik pada karet maupun kelapa sawit maka ini mengindikasikan adanya proses alih fungsi lahan. (4. Kasman, (2009), "Pengembangan Perkebunan Karet Dalam Usaha Peningkatan Ekonomi Daerah Dan Pendapatan Petani Di Provinsi Aceh" adapun tujun ini adalah upaya pemerintah untuk mengurangi jumlah pengangguran dan kemiskinan yang sesuai dengan rencana pembangunan jangka menengah 
sebesar 5,1 persen sulit untuk mencapai jika tidak ada upaya untuk mengembangkan sektor rill. (5. Haji Marguni Rangkuti, (2007), "Strategi Dakwah Islamiyah Terhadap Masyarakat Transmigrasi di Indonesia Kajian di Sumatra Utara". Kajian ini untuk mendapati srtategi dakwah yang efektif dan boleh memecahkan masalah-masalah sosial keagamaan masyarakat transmigran di Indonesia.

Berbagai artikel di atas, belum ada yang membahas tentang tantangan dakwah di perkebunan karet dan sawit. Padahal ini perlu dibahas, tantangan dakwah yang bagaimana yang harus dilalui mereka yang merasa terusik akan minimnya ilmu pengetahuan tentang agama islam. Karena mayoritas masyarakat transmigran sibuk dengan kegiatan mereka sebagai tani, karena rasa takut akan bertahan hidup. Berkebun dari pagi sampe larut malam, mereka tidak sadar akan pendidikan anakanak mereka yang terbengkalai. Dari penelitian terdahulu menunjukkan adanya perbedaan dengan makalah yang akan penulis buat. Dalam makalah ini bertujuan untuk mengkaji dakwah yang ada di perkebunan transmigrasi. Mereka bertahan dari keterpurukan ekonomi, tetapi juga mencari tahu dakwah yang bagaimana untuk membuat masyarakat bisa bersatu walaupun perbedaan budaya, agama, ras, yang sangat multikultural ini.

\section{PERMASALAHAN}

Melihat permasalahan diatas, yang menjadi permasalahan pada pembahasan tulisan ini adalah metode dan materi dakwah yang bagaimana untuk masyarakat transmigran di perkebunan karet dan kelapa sawit di desa Sumber makmur Palembang, yang menjadikan tantangan tersendiri bagi sebagian orang-orang yang resah akan minimnya masyarakat transmigran yang sadar akan pentingnya agama bagi mereka dan generasi selanjutnya.

\section{SEJARAH TRANSMIGRASI DAN PERKEBUNAN}

\section{Sejarah Transmigrasi}

Pulau Sumatera memiliki sejarah panjang migrasi penduduk dari Jawa. Sumatera merupakan jalur migrasi yang penting. Migrasi atau perpindahan penduduk ke Bengkulu bukanlah hal yang baru saja terjadi. Pada abad 17 orang-orang Bugis melakukan migrasi ke Bengkulu dan kemudian memiliki peran penting secara politik di wilayah ini. Migrasi orang-orang Jawa juga tinggi dinamikanya di Sumatera. Pada sensus penduduk yang dilakukan Belanda pada 1930 dari jumlah kelahiran orang Jawa di pulau lain, sekitar 767 ribu atau 92,2persen berada di Sumatera. Kala itu orang Jawa menjadi suku bangsa ketiga terbesar di Sumatera, sekitar 11,4persen di bawah suku Batak dan Minangkabau. Belakangan emigrasi menjadi salah satu program politik etis Belanda pada 1901 selain edukasi dan irigasi (Hatta, 1954: 43)

Sejarah transmigrasi di Bengkulu tak lepas dari sejarah hadirnya perkebunan sejak masa kolonial. Migrasi oleh negara dilakukan melalui kolonisatie atau pemindahan penduduk Jawa ke luar Jawa yang dilakukan pertama kali oleh Belanda sejak 1905, dan berlangsung hingga 1941. Ada 200 ribu orang yang dipindahkan (Levang 2003:10-11). Kolonisasi pertama dilakukan pemerintah Belanda pada 1905,

Islamic Comunication Journal Volume 3, Nomor 2, Juli-Desember 2018 
dengan memindahkan 155 keluarga dari Kedu ke Gedong Tataan, Lampung. Pada 1905 pemerintah Hindia Belanda memulai program kolonisasi ke Sumatera Barat, Bengkulu, Lampung dan Palembang. Sejak 1905 perkebunan-perkebunan di Sumatera Timur mengirim calo-calo mereka untuk membujuk petani-petani miskin pergi ke tanah Deli yang digambarkan sebagai sumber uang yang berlimpah-limpah. Pada 1908 kolonisasi kembali dilakukan di Bengkulu dan Sumatera Timur (Lih Notosusanto, 2008:105 ).

Transmigrasi adalah sebuah kebijakan pemerintah untuk memindahkan penduduk dari satu tempat ke tempat yang lain dalam wilayah negara Republik Indonesia. Karena itu, transmigrasi juga sering disebut sebagai kebijakan migrasi yang bersifat internal, karena hanya mengatur perpindahan penduduk di dalam negeri. Kebijakan transmigrasi pada awalnya dibuat untuk mengurangi kepadatan penduduk di Jawa yang mengalami penurunan tingkat kesejahteraan sosial dan ekonomi.

\section{Sejarah Perkebunan}

Palembang memiliki sejarah panjang perkebunan sejak masa kolonial Belanda. Perkebunan masa kolonial dibuka utamanya untuk melayani permintaan komoditas pasar, macam karet, sawit, kopi dan lada. Perusahaanmerupakan hasil dari program nasionalisasi perkebunanperkebunan Belandaoleh pemerintahan

${ }^{1}$ PTPN VII dibentuk melalui Peraturan Pemerintah Nomor 12 tahun 1996 tanggal 14 Februari 1996,yang merupakan penggabungan dari PT Perkebunan X (Persero), PT Perkebunan XXXI (Persero), Proyek Pengembangan PT Perkebunan XI (Persero) di Lahat, dan Proyek Pengembangan
Sukarno pada 1957. Salah satunya PT Perkebunan NusantaraVII, atau PTPN VII8 ${ }^{1}$, yang komoditas utamanya adalah karet. Kopi jugakomoditas utama, sebelum digantikan kelapa sawit. Pada 1995 ekspor kopiBengkulu mencapai 450 ribu ton (Hidayat,2008:144). Era Soeharto perizinan perkebunan sawit paling banyak dikeluarkan. Pada 1985 PT Daria Dharma Pratama mendapatkan HGU sawit pertama seluas 1.296 hektar di Sumatra Selatan.

Sedangkan Produksi hasil perkebunan Kabupaten Musi Rawas ${ }^{2}$ pada tahun 2014 adalah 1.544.044 Ton. yang meliputi:

a) Produksi hasil perkebunan 'tinggi' > 200.000 Ton, yang meliputi Kecamatan Muara Tara, Muara Lakitan dan Muara Kelingi.

b) Produksi hasil perkebunan 'sedang' $100.000 \quad 199.999$ Ton , yang meliputiKecamatan Rawas llir, Rupit, Jayaloka, Nibung dan BTS Ulu.

c) Produksi hasil perkebunan 'rendah' < 99.999 Ton yang meliputi Kecamatan RawasUlu, Muara Beliti, BKL Ulu, Karang Jaya, Tugumufyo, Purwodadi, Karang Dapo,Megang Sakti, Selangit dan Ulu Rawas.

Keberadaan sektor perkebunan menimbulkan adanya penyerapan tenaga kerja, dimanapada tahun 2004 penyerapan tenaga kerja (jiwa) perkebunan di Kabupaten Musi Rawasadalah 171.612 jiwit, berdasarkan data tersebut maka

PT Perkebunan XXIII (Persero) di provinsi Bengkulu. Dua yang pertama merupakan perkebunan milik Belanda yang beroperasi di Sumatera Selatan dan Lampung.

${ }^{2}$ Rencana tata ruang wilayah Musi Rawas, Sumatra Selatan, h. 41. 
pengelompokan penyerapantenaga kerja terbagi ke dalam tiga kelompok yaitu.:

1) Penyerapan tenaga kerja yang dikelompokan pada kelompok 'tinggi', yaitu sektor perkebunan yang memiliki kemampuan menyerap tenaga kerja > 10000 jiwa, yang meliputi Kecamatan Rupit, Muara Kelingi, Muara Lakitan, Muara Beliti, BKL Ulu, Karang Jaya, Megang Sakti.

2) Penyerapante naga kerja yang dikelompokanp ada kelompok' sedang'yaitu menyerap tenaga kerja antara 5000 - 9999 jiwa, yang meliputi Kecamatan Rawas llir, Rawas Ulu, Tugumulyo, Karang Dapo, Jayaloka, Nibung dan BTS Ulu.

3) Penyerapante naga kerja yang dikelompokanp ada kelompok' rendah'yaitu menyerap tenaga kerja > 4999 jiwa, yang meliputi Kecamatan Purwodadi, Selangit, Ulu Rawas.

Sedangkan selama ini, Nibung yang sebagian besar petani sawit dan karet sangat berpengaruh terhadap Negara Indonesia bersama. Karena 2 negara produsen karet alam terbesar dunia yaitu Thailand dan Malaysia, memberikan kontribusi sebesar 75 persen terhadap total produksi karet alam dunia. Khususnya Indonesia memberikan kontribusi sebesar 26 persen dan total produksi karet alam dunia. Berdasarkan data dan kecenderungan membaiknya harga karet alam pada beberapa tahun terakhir, diproyeksikan hingga tahun 2020 konsumsi karet alam dunia akan cenderung mengalami peningkatan rata-rata sebesar 2,6 persen per tahun. Hal ini sejalan dengan meningkatnya pendapatan, perekonomian negara berkembang khususnya pada negara-negara dengan populasi penduduk yang besarseperti India dan China.

\section{SELAYANG PANDANG DAERAH TRANSMIGRAN PERKEBUNAN DESA SUMBER MAKMUR, KEC. NIBUNG, KAB. MUARATARA, SUMATRA SELATAN}

\section{Masyarakat Transmigran Desa}

\section{Sumber Makmur}

Transmigrasi merupakan perpindahan penduduk dari suatu daerah yangpadat penduduk ke daerah lain yang jarang penduduknya di wilayah Republik Indonesia untuk tinggal menetap dalam rangka pembentukan masyarakat baruserta untuk membangun daerah, baik daerah yang ditinggalkan maupun yang didatangi dalam rangka pembangunan nasional (BPS, 2002: 41). Daerah transmigrasi memang sengaja dibangun oleh pemerintah RI sebagai tempat pemukiman penduduk yang dipindahkan atau pindah dari suatu daerah yang telah ditetapkan oleh pemerintah, dengan tujuan meningkatkan kesejahteraan hidup masyarakat. Penduduk yang bermukim disana berasal dari berbagai daerah yang datang dengan harapan akan memperoleh kehidupan yang lebih baik, sehingga banyak bermunculan anggapan-anggapan yang mengatakan bahwa orang orang yang mengikuti transmigrasi atau biasa disebut orang trans adalah orang buangan dari daerah asalnya, atau yang lebih menyakitkan lagi adalah orang yang melarikan diri dari daerah asalnya karena tidak bisa mendapatkan kehidupan yang layak. 
Kehidupan yang baru di daerah transmigrasi membawa banyak masalah yang tidak sedikit bagi para transmigran, termasuk masyarakat desa Sumber Makmur. Ketika mereka datang pada tahun 1984, begitu banyak permasalahan yang harus dihadapi. Keharusan menyesuaikan diri dengan lingkungan yang baru dan orang-orang yang sama sekali tidak mereka kenal yang datang dariberbagai daerah menimbulkan rasa gelisah, dan meningkatnya intensitas emosional. Mereka datang dari latar belakang sosial, ekonomi, dan budaya yang berbeda yang membuat mereka harus mempunyai jiwa besar untuk bisa menerima segala perbedaan yang ada.

Daerah Nibung adalah daerah transmigarasi dari bergabai macam suku dan budaya. Daerah Nibung sendiri adalah sebuah nama Kecamatan yang berlokasi di Kabupaten Musi Rawas Propinsi Sumatra Selatan Inndonesia. Secara Geografis Kecamatan Nibung mempunyai luas wilayah 67.750 H.a. dengan jumblah penduduk 20.884 jiwa yang terdiri dari 11.486 laki-laki 9.398 Perempuan, terdiri dari penduduk asli setempat, suku Bali, Sunda, Melayu dan Jawa. Pekerja atau mata pencaharian penduduk adalah bertani kelapa sawit dan karet. Kecamatan Nibung mempunyai 1 Kelurahan dan 10 Desa, jarak antar Kecamatan Nibung dan Kota Kabupaten Musi Rawas 180 KM dengan jarak tempuh 4 jam menggunakan kendaraan bermotor.

Awal masuk masyarakat transmigrasi pada tahun 1984 khususnya Desa Sumber Makmur, pada masa itu disana seperti

\footnotetext{
${ }^{3}$ Lihat Tim Penyusun Kamus Pusat Pembinaan dan
} Pengembangan Bahasa, Kamus Besar hutan belantara, jadi masyarakat yang datang disana yang tidak kuat bertani akan pulang lagi ketanah asalnya. Pada awal transmigrasi pemerintah memberikan lahan kepada para transmigran jawa sebesar 2,1/4 ha (hektar) untuk setiap KK (kepala keluarga). Tanah $2 \mathrm{Ha}$ (Hektar) itu adalah kebun Karet yang telah ditanam selama 2 tahun oleh PT Jamika bekerja sama dengan pemerintah, dan 1/4 hektar untuk pekarangan mencakup tempat tinggal dan pekarangan rumah. Sedangkan sambil menunggu karet bisa dipotong masyarakat tetap harus makan, dan mereka mau gak mau harus menjadi petani sayuran, buah buahan untuk mencukupi kebutuhan mereka. Kesibukan mereka mengesampingkan pendidikan umum anak, pendidikan agama anak, ngaji anak. Padahal urusan agama, pendidikan itu sangatlah penting tapi masyarakat Sumber Makmur belum sadar akan pentingnya semua itu.

\section{Karakteristik \\ Masyarakat \\ Transmigran Desa Sumber Makmur}

Karakteristik berasal dari akar kata karakter yang berarti sifat kejiwaan, akhlak atau budi perkerti yang membedakan seseorang dengan yang lain; tabiat; watak. Selanjutnya disebut karakteristik berarti mempunyai sifat khas sesuai dengan perwatakan tertentu. ${ }^{3}$ Berbicara tentang masalah primitif, maka kita akan berbicara tentang kehidupan masyarakat Tani. Begitu pula, kehidupan di daerah pertanian selalu dikaitkan dengan kehidupan agraris, yaitu kelompok masyarakat yang

BahasaIndonesia, (Cet. III; Jakarta: Balai Pustaka, 1990), 389 
mayoritas bermata pencaharian di bidang pertanian. Daerah pertanian sebagai penghasil pangan utama, menjadi tumpuan bagi masyarakat desa dan kota.

Keberhasilan kegiatan konservasi yang dilakukan oleh Masyarakat Musi Rawas sangat didukung oleh kondisi masyarakatnya yang bersifat:
a) Homogen ( Macam-macam sifat )
b) Memiliki kesadaran bersama
c) Adopter ( Pengadopsi )
d) Budaya kolektif
e) Persepsi positif pada kegiatan konservasi

Masyarakat homogen ditandai dengan karakteristik status sosial-ekonomi, pekerjaan, pendidikan yang hampir sama. Persamaan karakteristik pada masyarakat homogen, seperti masyarakat tani karet dan sawit di Musi Rawas memungkinkan mereka mengembangkan norma-norma konservasi tanah dengan cara melakukan minimum pengolahan lahan pada kegiatan pertanian dalam kawasan. Norma yang dikembangkan dan disepakati (communal norms), yaitu melarang penanaman tanaman singkong dan menganjurkan menanam tanaman perkebunan. Agrawal dan Gibson (1999:124) menjelaskan bahwa keberadaan norma bersama yang muncul karena kesamaan pandangan, identitas, pengalaman, kepentingan dan sebagainya tersebut yang kemudian diinternalisasi ke dalam perilaku masyarakat mampu memfasilitasi terbentuknya suatu gerakan untuk tujuan pengelolaan dan konservasi sumber daya alam.

Mayoritas petani yang ada di Nibung ini disektor pernatian kelapa sawit dan karet, awalnya ini adalah supsidi dari pemerintah tapi masyarakat transmigran diharuskan menunggu sampe bisa dipanen.Masa tunggu karet sendiri minimal 6 tahun, baru bisa dipanen. Dan awal trans hanya ada pohon karet, dan sawit masih menunggu agar bisa dipanen. Proses menunggu itu membutuhkan waktu yang tidak sedikit, maka masyarakat trans mulai bercocok tanam untuk makan seharihari. Setelah tahun 1989 awal-awal masyarakat memanen karet. Masyarakat mengahadapi permasalahan dalam penjualan karena harga beli karet masih sangat rendah jadi masih menjadi masalah perekonomian mereka.Tahun 2001 sawit sudah bisa dipanen dan itu bisa membangun perekonomian msyarakat transmigran yang ada di Nibung.

Sedangkan Menurut Landis (Ridwan. 2012:4) (ilmuan sosiologis), terdapat beberapa karateristik masyarakat desa yang perlu dipahami, antara lain yaitu umumnya mereka curiga terhadap orang luar yang masuk. Para orang tua umumya otoriter terhadap anak-anaknya. Cara berfkir dan sikapnya konservatif dan statis. Mereka amat toleran terhadap nilai-nlai budayanya sendiri, sehingga kurang toleran terhadap budaya lain. Adanya sikap pasrah menerima nasib dan kurang kompetitif. Memiliki sikap kurang komunikatif dengan kelompok sosial diatasnya. Seluruh ciri atau karakteristik masyarakat perkebunan di atas sangat berpengaruh terhadap konsep berdakwah di pedesaan. Bagaimana seorang dai dapat menyesuaikan metode dakwahnya dengan keadaan masyarakat transmigran yang cenderung menerima sikap pasrah dan kurang komunikatif dengan orang golongan lain. Tentu tidak dapat dipungkiri

Islamic Comunication Journal Volume 3, Nomor 2, Juli-Desember 2018 
bahwa dalam proses dakwah dan pendidikan Islam memegang peranan sangat penting. Meskipun terdapat perdebatan dan diskusi yang panjang mengenai kedatangan Islam ke Nusantara, tapi telah disepakati oleh para sejarawan Islam bahwa proses dakwah dan perkembangan Islam melalui dakwah dan pendidikan oleh muballig-muballigh Islam selanjutnya setelah Islam sampai di Nusantara dilakukan oleh orang-orang Islam sendiri. (A. Hasjmy, 1989: 7).

\section{Kegiatan Masyarakat Transmigran Desa Sumber Makmur}

Pertemuan berbagai macam etnis yangmemiliki perbedaan tata bahasa, mengakibatkan sulitnya proses komunikasi. Belum lagi benturan-benturan ekonomi, sosial, agama, terutama benturan budaya yang menimbulkan suasana yang tidak harmonis turut mewarnai kehidupan para transmigran. Kecemburuan dari penduduk asli daerah semakin memperparah keadaan, akibat dari adanya perbedaan perlakuan dari pemerintah terutama fasilitas yang diberikan kepada para transmigran baik berupa alat produksi, maupun lahan-lahan perkebunan. Fasilitas yang diberikan kepada para transmigran mulai dari perumahan, pembukaan lahan usaha, sarana air bersih sampai kepada sertifikat hak milik lahan, merupakan perlakuan yang sangat tidak adil dibanding terhadap penduduk lokal yang tidak jarang menyulut konflik horizontal, dan menghambat proses pembauran. Juga pandangan negative tentang orang trans, bahwa mereka telah merebut tanah orang lain membuatnilai para transmigran sangat rendah di mata penduduk asli daerah.
Sektor perkebunan menjadi sumber mata pencaharian utama bagi sebagian besar masyarakat kecamatan Nibung, kabupaten Musirawas Palembang, disamping sector perdagangan, transportasi, perbengkelan, rumah makan dan pendidikan. Dampak positif kehadiran perkebunan karet dan kelapa sawit adalah terbukanya lapangan kerja bagi masyarakat sekitar sebagai sumber penghasilan bagi masyarakat yang tidak memiliki kebun karet, ataupun bagi masyarakat yang menginginkan pendapatan tambahan.

Daerah Nibung adalah daerah transmigarasi dari bergabai macam suku dan budaya karena di daerah Nibung sendiri terdiri dari 11 desa yang dihuni oleh masyarakat pendatang dan masyarakat asli Palembang. Sedangkan yang akan kita bahas disini fokus di desa Sumber Makmur terderi dari Blok A diisi masyarakat asli Dusun, Blok B masyarakat Jawa Barat, Blok C masyarakat campuran antara Palembang asli dan Jawa Barat, Blok Dmasyarakat Palembangasli, Blok E masyarakat Jogja, Blok F Masyarakat Jogja, Blok G masyarakat Demak dan Jogja, Blok H Masyarakat Bali.

Transmigrasi di Nibung pada tahun 1984, di awal transmigran masyarakat masih fokus pada mata pencaharian untuk makan sehari-hari karena dari pemerintah dikasih lahan kosong saja. Diberi modal tempat tinggal dan kebun untuk bertani, karena tanah di Sumatra tidak sebagus tanah di Jawa yang subur bila ditanami tanaman yang mempunyai akar pendek contoh (padi, terong, jagung, cabe dll). Tapi di Nibung ini lebih bagus ditanami pohon karet dan sawit karena kondisi tanah yang sangat keras dan bagus untuk posisi tanaman yang berakar dalam dan besar. 
Hampir 6 tahun dari pembukaan lahan untuk perkebunan karen dan sawit masyarakat banyak yang sibuk dengan urusan perekonomian sendiri-senidiri. Mereka banyak yang kuatir tentang pendidikan anak-anaknya. Para orang tua berkebun di kebun karet berangkat dari habis shubuh dan pulang jam 11 siang. Sedang alat bertani sawit dari pagi jam 6 pagi sampe menjelang magrib. Banyak anak-anak yang berkeinginan kuat untuk belajar tapi tidak mendapat motivasi orang tua. Akhirnya memunculkan keresahankeresahan dari kalangan orang tua yang terpelajar. Mereka mengumpulkan pemuda untuk meramaikan pendidikan, khususnya pendidikan Islam. Pelopor pertama Ust. Jakfar Sodik (Jogja), H. Abdul Aziz (Demak), H. Mahfudhon (Demak), H. Imam Muali (Dusun) dan beliau adalah seoarang guru, Sujianto (TNI) babinsa yang tugas di Nibung masa itu. Mereka merangkul pemuda pemudi untuk belajar agama, ia membuka ngaji kitab habis dhuhur khusus remaja-remaja. Dan memembuka sekolah Diniah untuk anakanak usia dini, mengadakan ekstra qiraah di masjid Agung dan mendatangkan pelatih dari luar.

Awalnya kegiatan itu sangat sulit dilakukan karena remaja yang lulusan SMA ikut berkebun kelapa sawit yang berangkat pagi sampai sore hari. Akhinya Ust.Jakfar dan teman-teman mendekati orang tua mereka agar mengadakan yasinan untuk bapak-bapak dan dhibaan untuk ibu-ibu. Diakhir yasinan dan dhibaan diadakan tausiah sebentar untuk mengajak anak-anak mereka aktif dalam belajar agama tidak hanya disekolah pagi saja. Ust.Jakfar dan kawan-kawan menginginkan anak-anak mereka yang lulusan SD, SMP agar di sekolahkan diluar atau dipondokkan agar ada generasi penerus yang pintar-pintar di Kec. Nibung.

Awal tahun 2000 mungkin sangat terlihat adanya perubahan, setelah perekonomian terangkat dari hasil perkebunan sawit dan karet yang sudah ada hasilnya. Pendidikan yang sudah berjalan sebagaimana mestinya, akan tetapi masih belum ada SMA sederajat jadi lulus SMP harus hijrah keluar desa. Setelah dibangun sekolah diniyah, diadakan pesantren kilat, kumpulan-kumpulan pemuda desa, dan antusias orang tua yang menyekolahkan anak ke perguruan tinggi. Semua itu atas dukungan orangtua yang telah sadar bagaimana pentingnya masa depan.

Urgensi dakwah dalam proses Islamisasi dan pembaharuan dakwah di daerah perkebunan, tentu tidak lepas dari kreativitas muballigh dan tokoh-tokoh Islam yang turut mengambil peran penting dalam proses Islamisasi dan perkembangan Islam. Mereka ini tersebar diseluruh pelosok Nusantara. Tidak berbeda halnya dengan proses dakwah dan perkembangan Islam di daerah Sumber Makmur, Nibung, Palembang yang merupakan bagian dari Sumatera Selatan. Karena itu penelitian ini mencoba menemukan metode-metode dari perjuangan dalam aspek pengembangan dan pembaharuan dakwah Islam di Sumber Makmur. Sesungguhnya banyak hal yang perlu diungkap dan diketahui berkaitan dengan usaha yang dilakukannya dalam proses dakwah dan perkembangan Islam di daerah Sumber Makmur dan sekitarnya.

\section{TANTANGAN DAKWAH DI} MASYARAKAT TRANSMIGRASI DESA. SUMBER MAKSMUR, KEC. 


\section{NIBUNG, KAB. MUARA TARA, SUMATRA SELATAN}

\section{Tinjauan Teoritis}

Menurut S.M. Nasaruddin Latif dakwah adalah kegiatan dengan lisan atau tulisan dan lainnya yang bersifat menyeru, mengajak, memanggil manusia lainnya untuk beriman dan mentaati Allah dan Rasul- Nya, sesuai dengan garis-garis aqidah, syari'at, serta akhlak Islamiyah (Siti Muriah, 2000: 4). Dengan pengertian ini, dapat dipahami bahwa dakwah merupakan kegiatan yang memiliki unsurunsur kompleks yang berfungsi:

a) Dakwah berfungsi untuk menyebarkan Islam kepada manusia sebagai individu dan masyarakat.

b) Dakwah berfungsi melestarikan nilainilai Islam dari generasi ke generasi berikutnya.

c) Dakwah berfungsi korektif, artinya meluruskan akhlak yang bengkok, mencegah kemungkaran dan mengeluarkan manusia dari kegelapan moral (Moh. Ali Aziz, 2004: 58).

Dengan konsep yang demikian, dakwah dapat dipahami dalam terminologi, Islamisasi dan pembaharuan. Term "pembaharuan" merupakan bagian integral dari konsep dakwah, meskipun pengertian yang dikandung dalam kata. Pembaharuan juga menyangkut dengan usaha untuk menyesuaikan paham-paham keagamaan Islam dengan perkembangan baru yang ditimbulkan kemajuan ilmu pengetahuan dan teknologi modern. Pembaharuan juga dapat diberi makna usaha-usaha untuk menyelaraskan realitas-realitas masyarakat Islam dengan konsep-konsep Islam, atau dengan kata lain disebut dengan Pemurnian agama, atau puritanisme (Harun Nasution, 1975: 23).

Penyebaran Islam di Nusantara tidak dapat dilepaskan dari aktivitas dakwah dan pembaharuan Islam. Kedua aspek ini merupakan suatu proses yang sangat penting dalam sejarah Indonesia. Meskipun disadari bahwa terdapat banyak masalah yang perlu dikaji lagi secara kritis untuk memahami proses perkembangan Islam tersebut lebih komprehensif. Di antara beberapa faktor yang cukup penting untuk dipahami dan dikaji dalam proses dakwah dan perkembangan Islam adalah menyangkut kegiatan-kegiatan proses Islamisasi dan pembaharuan Islam yang sesungguhnya adalah bagian dari watak Islam itu sendiri, yang dapat ditangkap dan dipahami oleh umat Islam melalui pemikiran-pemikiran para tokohnya.

Sesungguhnya bukanlah sesuatu yang paradoks, jika Islam sebagai agama wahyu yang universal dan bertolak dari kesempurnaan dan keabadian doktrin menampakkan dirinya dalam keragamaan yang diwarnai oleh perjalanan sejarah dan situasi sosial kultural dari masyarakat pemeluknya. Meminjam ungkapan Taufik Abdullah (1987, 1), bahwa ketegangan antara doktrin yang abadi dengan manifestasi dalam kehidupan pribadi maupun sosial, merupakan faktor utama dari dinamika Islam. Dalam sejarah Islam kelihatan ketika ketegangan itu tak lagi dirasakan maka periode kejumudan dan keterlenaan intelektual dan keterbelakangan sosialpun akhirnya muncul. Karena itu sesungguhnya dapat dipahami bahwa munculnya para pemikir, pembaharu, merupakan pertanda kesadaran tentang ketegangan yang kreatif 
antara doktrin yang abadi dan universal itu dengan manifestasi yang beraneka ragam. Senada dengan Taufik Abdullah, Azyumardi Azra (2007: xix) lebih jauh mengemukakan bahwa memahami proses transmisi gagasan pembaharuan itu menjadi semakin penting dalam hubungannya dengan perjalanan Islam di Nusantara. Karena kawasan ini secara geografis terletak pada pinggiran dunia muslim, terdapat kecenderungan di kalangan sarjana dan peneliti modern untuk tidak memasukkan Nusantara (Indonesia) dalam pembaharuan Islam, dengan asumsi bahwa Islam kawasan ini tidak mempunyai tradisi keilmuan yang mantap.

\section{Teori Perubahan Sosial}

Para ahli filsafat, sejarah, ekonomi dan para sosiolog telah mencoba untuk merumuskan prinsip-prinsip atau hukumhukum perubahan-perubahan sosial. Banyak yang berpendapat bahwa kecenderungan terjadinya perubahanperubahan sosial merupakan gejala wajar yang timbul dari pergaulan hidup manusia. Yang lain berpendapat bahwa perubahan sosial terjadi karena adnya perubahan dalam unsur-unsur yang mempertahankan keseimbangan masyarakat seperti perubahan dalam unsur-unsur geografis, biologis, ekonomis, atau kebudayaan. Beberapa sosiolog berpendapat bahwa ada kondisi-kondisi sosial primer yang menyebabkan terjadinya perubahanperubahan pada aspek-aspek kehidupan sosial lainnya. Sebaliknya ada pula yang mengatakan bahwa semua kondisi tersebut sama pentingnya, satu atau semua akan menelorkan perubahan-perubahan sosial.
Teori siklus, memandang bahwa perubahan sosKal merupakan rotasi perubahan alamiah yang akan terus terjadi. Ibnu khaldun sebagaimana dikutip oleh Robert H. Louer, menyebutkan perubahan kebudayaan bangsa akan selalu diawali dengan adanya bangsa yang mengembara, lalu menetap, kemudian membangun peradaban dan menikmati hasil-hasilnya dan selanjutnya akan mengalami kehancuran dengan digantikan oleh peradaban bangsa lain. Faktor pendorongnya adalah rasa solidaritas yang tinggi, sifat sosial dan agresif. Arnold Toynbee, mempunyai pendapat yang hampir sama dengan Ibnu Khaldun, bahwa perubahan sosial diawali dengan proses kelahiran, pertumbuhan, kemunduran dan kehancuran. Siklus ini akan berjalan terus menerus asalkan ada faktor pendorognya. Faktor pendorong yang dimaksud adalah keras lembutnya tantangan dan adanya "elit-kreatif". Terbentuknya perubahan sosial akan selalu diawali dengan adanya tantangan yang memadai, yang mendatangkan tanggapan yang memadai pula.

\section{Peranan Ulama Dalam \\ Mengembangkan Dakwah Di \\ Perkebunan Karet Dan Kelapa \\ Sawit Transmigran Sumber \\ Makmur Palembang}

Islam di wilayah perkebunan sawit dan karet di daerah transmigran Sumber Makmur brtumbuh dan mulai maju saat para transmigran datang, yang telah melakukan perpindahan penduduk dari pulau Jawa ke pulau Sumatra pada tahun 1884. Meskipun pada saat itu di wilayah tersebut sudah ada penduduk asli yang 
sudah beragama Islam namun hanya sebagai identitas dan sebagaian para peserta transmigran juga beragama Islam hanya sebatas identitas. Karena sebagian besar masih banyak yang belum memahami bahkan tentang pengetahuan agama Islam sangat minim sekali (wawancara Kades Sumber Makmur, Bapak Sururi 12-3-2017 ).

Apabila seseorang melaksanakan hak dan kewajiban sesuai dengan kedudukannya maka dia menjalankan peranannya. Pembedaan antara kedudukan atau peranan adalah untuk kepentingan ilmu pengetahuan, kedua tidak dapat dipisahkan tidak ada peranan tanpa kedudukan tanpa peranan. Setiap orang mempunya macam-macam peran yang berasal dari pola-pola pergaulan hidupnya hal itu sekaligus berarti bahwa menentukan apa yang di berikan oleh masyarakat kepadanya (Soerjono, 1990).

Bapak Sururi mengemukakan bahwa, di Desa Sumber Makmur dengan keadaan Islam yang belum kondusif dengan adanya pencampuran berbagai macam agama, dengan kasus kriminalitas yang sangat tinggi, tapi mereka mempunyai hubungan keluarga yang harmonis contohnya, kalau salah satu warga punya hajatan tanpa di undang orang satu RW datang untuk mengundang. Kalau ada musibah tanpa disuruh aparat desa dan orang-orang yang ada kesempatan langsung membantu, seperti dalam pembangunan masjid atau madrasah begitu diumumkan orang membantu semampunya.

\section{Tokoh Yang Berperan Dalam Perkembangan Dakwah Di Perkebunan Karet Dan Kelapa}

\section{Sawit Transmigran Sumber Makmur Palembang}

Tokoh masyarakat merupakan seseorang yang berpengaruh dan mempunyai kedudukan (status) serta di tokohkan oleh lingkungannya. Penokohan tersebut karena pengaruh posisi, kedudukan, kemampuan, dan kepiawaiannya. Segala tidakan dan ucapan seorang tokoh akan diikuti oleh masyarakat yang di sekitarnya. Secara abtrak, kedudukan berarti tempat seseorang dalam suatu pola tertentu. Dengan demikian seorang dikatakan mempunyai beberapa kedudukan, oleh karena seseorang biasanya ikut serta dalam berbagai pola kehidupan. Didalam masyarakat umumnya ada beberapa kedudukan, kedudukan disini yaitu (assigned-status) yang artinya suatu kelompok atau golongan memberikan kedudukan yang lebih tinggi kepada seseorang yang berjasa, yang telah memperjuangkan sesuatu untuk memenuhi kebutuhan dan kepentingan masyarakat (Soerjono, 1990).

Adapun tokoh-tokoh dalam perkembangan dakwah Islam di daerah transmigran Desa Sumber Makmur seperti : 1. Ust. Jakfar Sodik (Jogja) 2. H. Abdul Aziz (Demak) 3. H. Mahfudhon (Demak) 4. H. Imam Muali (orang asli Palembang) dan beliau adalah seoarang guru 5. Sujianto (TNI). Salah satu tokoh yang masih hidup sampe sekarang salah satunya adalah bapak Imam Muali dia merupakan salah satu tokoh yang sekarang dalam memajukan dan mengembangkan agama Islam di daerah transmigran Desa Sumber Makmur. Sejak awal transmigrasi dan berdirinya Desa Sumber Makmur dia menjadi sosok yang di dengar omongannya 
oleh masyarakat dia merukan orang asli dari penduduk Palembang. Saat berdirinya Desa Sumber Makmur dia diberi amanat menjadi Kepala Sekolah SDN Negri 1 Sumber Makmur. Selam kurang lebih 10 tahun lamanya dia menjadi kepala desa. Akhirnya, satu demi satu indikasi dari kemajuan Islam di desa Sumber Makmur terbangun, seperti tempat ibadah, sekolah berbasis agama Islam dan dia diberi kepercayaan untuk mengordinir bersama pemuda-pemuda setempat untuk membangun bersama masyarakat desa Sumber Makmur.

\section{Metode Yang Di Gunakan Dalam Mengembangkan Dakwah Di Perkebunan Karet Dan Kelapa Sawit Transmigran Sumber Makmur}

Perkembangan Islam yang sangat luas mendorong munculnya para ulam dan Mubalig. Para ulama dan Mubaligh menyebarkan Islam melalui pendidikan dengan mendirikan pondok-pondok pesantren di berbagai daerah. Penyebaran Islam tidak dapat di lepaskan dari peranan para Wali. Ada Sembilan wali yang menyebarkan Islam denga cara berdakwah, yang di sebut juga Walisongo. Mereka di kenal telah memiliki ilmu serta penghayatan yang tinggi terhadap agama Islam. Dengan demikian, masyarakat akan dengan mudah menangkap dan memahami ajaran Islam (Artikelsiana: 2016).

Dakwah adalah salah satu proses penyampaian pesan oleh komunikator dengan mempergunakan lambing bangsa guna mengubah tingkah laku manusia (Daud: 1994). Bisanya yang disampaikan dalam materi dakwah adalah ajaran agama
Islam tentang berbagai persoalan hidup dan kehidupan manusia. Dakwah yang berarti menerapkan atau melaksanakan ajaranajaran Islam dalam berbagai aspek hidup dan kehidupan menentukan kepada kita umat Islam umumnya. Pertama, keterampilan memahami, merumuskan, kehidupan umat, secara definitif. Kedua, memiliki ketrampilan untuk memahami wahyu sebagai petunjuk untuk diaplikasikan, menjawab tantangan situasi dan kondisi dalam kehidupan sehari-hari (Surjadi: 1998).

Secara umum, dapat dikatakan bahwa metode dakwah para para tokoh yang ada di daerah transmigrasi tidak terlepas dari metode yang digunakan oleh mereka dalam Walisongo khusus seperti pemimpin, orang terpandang dan terkemuka dalam dalam masyarakat, seperti para bupati, adipati, raja-raja ataupun menghadapi para bangsaan lainnya. Dasar dari metode ini merujuk kepada Al-Qur'an surah an-Nahl : 125.

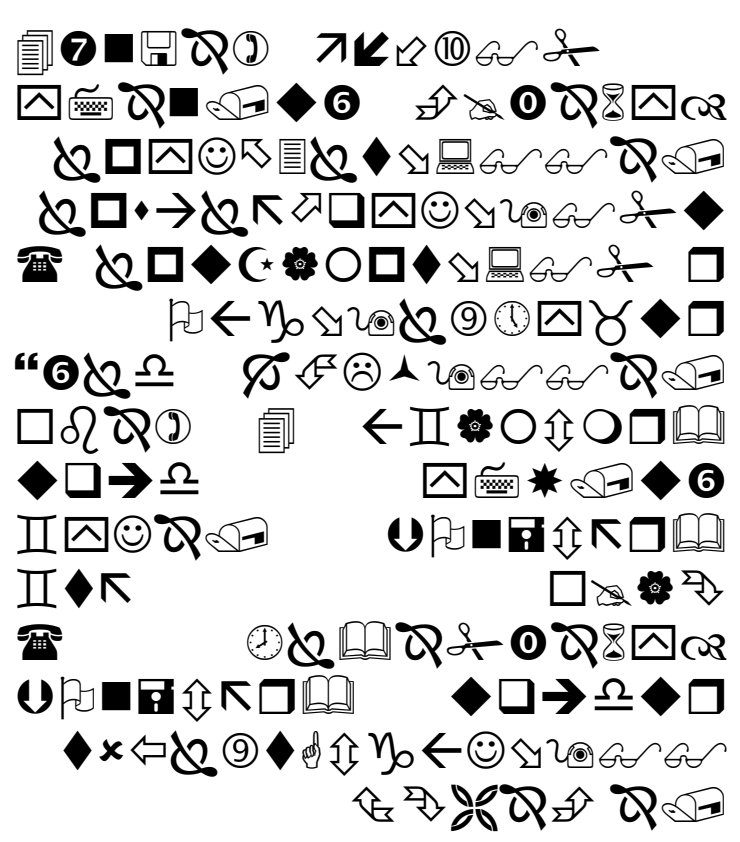

Artinya: "serulah (manusia) kepada jalan Tuhan-mu dengan hikmah

Islamic Comunication Journal Volume 3, Nomor 2, Juli-Desember 2018 
Tantangan dakwah di perkebunan...hal. 207-226

[845] dan pelajaran yang baik dan bantahlah mereka dengan cara yang baik. Sesungguhnya Tuhanmu Dialah yang lebih mengetahui tentang siapa yang tersesat dari jalan-Nya dan Dialah yang lebih mengetahui orang-orang yang mendapat petunjuk.[845] Hikmah: ialah Perkataan yang tegas dan benar yang dapat membedakan antara yang hak dengan yang bathil."

1. Adapun beberapa metode yang amat penting dalam berdakwah secara global menjadi tiga macam. Diantaranya adalah sebagai berikut:

\section{a) AI-Hikmah}

Hikmah merupakan peringatan kepada juru dakwah untuk tidak menggunakan satu bentuk metode saja. Sebaliknya, mereka harus menggunakan berbagai macam metode sesuai dengan realitas yang dihadapi dan sikap masyarakat terhadap agama Islam. Sudah jelas bahwa dakwah tidak akan berhasil menjadi suatu wujud yang riil jika metode dakwah yang dipakai untuk menghadapi orang bodoh sama dengan yang dipakai untuk menghadapi orang terpelajar. Kemampuan kedua kelompok tersebut dalam berfikir dan menangkap dakwah yang disampaikan tidak dapat disamakan, daya pengungkapan dan pemikiran yang dimiliki manusia berbeda-beda. Hikmah merupakan pokok awal yang harus dimiliki oleh seorang da'i dalam berda "wah. Karena dengan hikmah ini akan lahir kebijaksanaan-kebijaksanaan dalam menerapkan langkah-langkah dakwah. baik secara metodologis maupun praktis. Oleh karena itu, hikmah yang memiliki multi definisi mengandung arti dan makna yang berbeda tergantung dari sisi mana melihatnya. (Pimay, 2006:3).

\section{b) AI- Mau 'idza Al-Hasanah}

Mengandung arti kata-kata yang masuk ke dalam kalbu, penuh kasih sayang ke dalam perasaan dengan penuh kelembutan, tidak membongkar atau membeberkan kesalahan orang lain sebab kelemah lembutan dalam menasehati sering kali dapat meluluhkan hati yang keras dan menjinakkan kalbu yang liar, ia lebih mudah melahirkan kebaikan dari pada larangan dan ancaman (Pimay, 2006 : $37)$.

c) Al-Mujadalah Bi-al-Lati Hiya Ahsan

Merupakan tukar pendapat yang dilakukan oleh dua pihak secara sinergis, yang tidak melahirkan permusuhan dengan tujuan agar lawan menerima pendapat yang diajukan dengan memberikan argumentasi dan bukti yang kuat. Antara satu dengan lainnya saling menghargai dan menghormati pendapat keduanya berpegang kepada kebenaran, mengakui kebenaran pihak lain dan ikhlas menerima hukuman kebenaran tersebut (Pimay, 2006:38).

2. Unsur-unsur dakwah adalah komponen yang selalu ada dalam setiap kegiatan dakwah. Diantaranya adalah:

\section{a) Da'i (Pelaku Dakwah)}

Kata da"ei ini secara umum sering disebut dengan sebutan mubaligh (orang yang menyampaikan ajaran Islam) namun sebenarnya sebutan ini konotasinya sangat sempit karena masyarakat umum cenderung mengartikan bahwa mubaligh sebagai seorang yang menyampaikan 
ajaran Islam nelalui lisan seperti penceramaah agama, khatib (orang yang berkhutbah), dan sebagainya. Dalam kegiatan dakwah peran dai sangatlah esensial, sebab tanpa dai ajaran Islam hanyalah ideologi yang tidak terwujud dalam kehidupan masyarakat. Biar bagaimanapun baiknya ideologi Islam yang harus disebarkan di masyarakat, ia akan tetap sebagai ide, ia akan tetap sebagai cita-cita yang tidak terwujud jika tidak ada manusia yang menyebarkannya (Hasyim, 1974: 162).

Citra dai menjadi hal yang sangat penting dalam menyampaikan dakwah di daerah perkebunan transmigran dibandingkan dengan isi dakwah itu sendiri karena sifat masyarakat desa yang sangat menghargai orang-orang yang berilmu dan jiwa sosialitasnya yang tinggi. Pelopor penggerak dalam dakwah yang ada di Desa Transmigrasi yaitu pertama Ust. Jakfar Sodik (Jogja), H. Abdul Aziz (Demak), H. Mahfudhon (Demak), H. Imam Muali (Dusun) dan beliau adalah seoarang guru, Sujianto (TNI). Mereka mendatangkan Kiai dari Jawa Timur Ust.H. M. Fadli yang di buatkan rumah di sebelah Masjid Agung Desa Sumber Makmur. Beliau sangat mendukung dengan adanya pelopor semangat dalam hal kebaikan ini. Mereka berjuang bersama untuk memajukan masyarakat yang ada di desa Sumber Makmur, dari hal memotivasi toleransi sesama umat, bertahan hidup dari masa penantian perkebunan mereka yang belum bisa di panen. Belajar perbedaan bahasa antar suku dan budaya agar tidak ada kesalah pahaman dalam berbicara.

b) Mad'u (Penerima Dakwah)
Mad'u, yaitu manusia yang menjadi sasaran dakwah atau manusia penerima dakwah, baik sebagai individu maupun sebagai kelompok, baik manusia yang beragama Islam maupun tidak, atau dengan kata lain manusia secara keseluruhan. Mad'u (penerima dakwah) terdiri dari berbagai macam golongan manusia. Oleh karena itu, menggolongkan mad'u sama dengan menggolongkan manusia itu sendiri misalnya profesi, ekonomi dan seterusnya (Aziz, 2004: 90).

Mad'u berasal dari masyarakat transmigrasi dari berbagaii macam suku dan terdiri dari 11 desa yang dihuni oleh masyarakat pendatang, terdiri dari 8 Blok/RW. Pemuda pemudi dan anak desa Sumber Makmur juga bayak yang menginginkan untuk belajar agama. Mereka rela berbondong-bondong untuk datang ke masjid yang jaraknya memakan waktu tempuh setengah jam untuk sampai ke masjid Agung Desa. Hal itu lambat laun menjadi masalah tersendiri bagi Da'i dikarenakan masjid yang jauh membuat masyarakat lama-lama berkurang yang datang ke masjid. Akhirnya inisiatif masyarakat setiap blok/RW di buatkan mushola untuk belajar agama. Tokohtokoh akhirnya yang mendatangi setiap mushola yang ada di blok/RW tersebut.

c) Maddah Dakwah (Materi Dakwah)

Materi dakwah adalah pesan yang disampaikan oleh dai kepada mad'u yang menggandung kebenaran dan kebaikan bagi manusia yang bersumber Al-qur'an dan hadits. Ajaran Islam itu sendiri yang dijadikan maddah dakwah Islam karena ajaran Islam yang sangat luas. Meliputi akidah, syariat dan akhlaq dengan berbagai 
macam cabang ilmu yang diperoleh darinya. (Aziz, 2004: 194)

Materi di pedesaan biasanya lebih bersifat agamis atau belajar tentang dasar agama, karena masih banyak orang-orang tua yang masih awam, seperti pengajaran tentang ibadah, dasar dasar fikih tentang (sholat, zakat, nikah dsb), akhlak dan muamalah. Di Desa Sumber Makmur, masih banyak masyarakat yang minim pengetahuan tentang fikih, terutama ibu ibu contohnya saja bagaimana hukum darah haid, nifas, dan darah istiadhoh. Hukumnya dan hitungan harinya, sholat atau tidak, banyak masyarakat yang belum mengetahui itu. Da'i sebelum memberi materi, sesudahnya telah membelajari apa materi yang harus disampaikan ke masyarakat. Hal yang sangat penting adalah perlunya perhatian serius terhadap citra da'i yang mendampingi mad'u. Hal inilah yang menjadi tumpuan harapan di dalam menjalankan strategi dakwah pada masyarakat transmigran. Masyarakat pedesaan tidak begitu suka dengan materi dakwah yang disangkut pautkan dengan ilmu pengetahuan dan teknologi ataupun politik.

d) Metode Dakwah secara tatap muka (face to face)

Dakwah secara tatap muka dipergunakan apabila mengharapkan efek perubahan tingkah laku (behavior change) dari mad'u. Da'i dan mad'u dapat saling melihat secara langsung dan bisa mengetahui apakah mad'u memperhatikan dan mengerti apa yang disampaikan. Sehingga umpan balik tetap menyenangkan. Kelemahannya mad'u yang dapat diubah tingkah lakunya relatif, sejauh bisa berdialog dengannya. Karena setelah kita melihat paparan diatas tentang kebiasaan masyarakat yang harus jemput bola untuk mengingatkan adanya pengajian, perkumpulan tentang agama, semua itu harus dengan dakwah face to face.

Metode dakwah kepada masyarakat perkebunan transmigrasi yang mayoritas bertani dan berkebun biasanya secara langsung melalui pengajian, tabligh akbar dan face to face, hal ini disebabkan karena waktu dan rutinitas yang dilakukan orang transmigran relatif masih rendah atau masih banyak waktu kosong serta sikap individualismenya masih tinggi, dan menjadikan masjid atau musholah sebagai tempat utama dalam berdakwah serta pesantren sebagai tempat utama untuk pendidikan anaknya.

Tokoh-tokoh pelopor yang merangkul pemuda dan pemudi di desa transmigrasi Sumber Makmur harus berjuang keras untuk selalu mengingatkan semua kalangan tentang pentingnya toleransi sesama masyarakat yang beda budaya, agama dan bahasa. Melalui face to face dan dor to dor.

\section{e) Sarana}

Sarana dakwah diwilayah perkebunan desa trasmigran ini sudah sangat memadai, contohnya saja di setiap RT sudah mempunyai mushola dan di wilayah Blok itu mempunyai 1 Masjid. Masalahnya disana semangat mayarakat untuk datang ke mushola dan masjid sangat minim. Banyak yang mengutamakan berkebunnya, daripada harus mengali ilmu agama.Sarana RT dan RW disediakan, agar masyarakat 
termotivasi untuk sholat berjamaah mengaji. Ada sebagian mushola di tiap tiap RT yang ramai danada yang tidak. Karena di Desa Sumber Makmur ada sebagian Masyarakat yang semangat danada msyarakat yang tidak semangat dan mereka mengutamakan berkebunnya.

Memperhatikan uraian di atas, maka dapat dikatakan bahwa metode dakwah pada masyarakat transmigran sangat diperlukan. Dengan kondisi masyarakat transmigran yang cenderung memiliki waktu yang terbatas di waktu malam dan lebih banyak bekerja pada siang hari serta lebih banyak di rumah pada malam hari, maka langkah dakwah yang strategis adalah dakwah melalu face to face dari rumah ke rumah. Masyarakat agraris cenderung membutuhkan tempat bertanya masalah-masalah agama setiap saat. Oleh karena itu, pada kondisi tersebut mendorong dai untuk melaksanakan pendampingan terhadap mad'u, agar mereka mudah menyelesaikan masalahnya dengan tepat waktu.

\section{KESIMPULAN}

Kondisi sosial kemasyarakatan di transmigran, di Desa Sumber Makmur terletak di daerah dataran tinggi dan jauh dari keramaian kota, dengan mata pencaharian yang relatif sama antar warganya. Pencaharian utama adalah berkebun (lebih mengutamanakan potensi alam), dan sangat bersifat toleran dalam arti sangat mementingkan aspek kebersamaan dan kekeluargaan antar sesama warga di desanya. Kegiatan Masyarakat transmigran, salah satu ciri khas dalam kehidupan masyarakat desa adalah adanya semangat gotongroyong yang tinggi. Misalnya pada saat mendirikan rumah, memperbaiki jalan desa, membuat saluran air dan sebagainya. Gotong royong semacam ini lebih dikenal dengan sebutan kerja bakti, terutama menangani hal-hal yang bersifat kepentingan umum.

Kurang menghargai ilmu pengetahuan dan teknologi modern, jumud dan statis.Kondisi masyarakat transmigran sebagai petani yang cenderung memiliki waktu yang terbatas di waktu malam dan lebih banyak bekerja pada siang hari serta lebih banyak di rumah pada malam hari, maka langkah dakwah yang strategis adalah dakwah melalui face to face atau melalui rumah ke rumah.Masyarakat transmigrasi Nibung cenderung butuh tempat bertanya masalah-masalah agama setiap saat. Oleh karena itu, mendorong dai untuk melaksanakan pendampingan terhadap mad'u agar mereka mudah menyelesaikan masalahnya dengan tepat waktu. Materi dakwah yang tepat buat mereka adalah masih berkisar pada aqidah, akhlak dan muamalah. Hal yang sangat penting adalah perlunya perhatian serius terhadap citra dai yang mendampingi mad'u.

\section{DAFTAR PUSTAKA}

Agrawal, A dan Gibson, C.C. (1999). Enchantment and disenchantment: the role of community in natural resource conservation. World Development,

Arifin, Anwar. Dakwah Kontemporer: Sebuah Studi Komunikasi (Cet.I; Yogyakarta: Graha Ilmu, 2011.

Arndt H.W. dan Sundrum. Transmigration: land settlement or regional 
development? Dalam Bulletin of Indonesian Economic Studies 13 (3):72-90. 1977.

Asmuni Syukir. Dasar-dasar Strategi Dakwah Islam. Surabaya: alIkhlas. 1983.

Asmuni, Syukir. Dasar-dasar Strategi Dakwah Islam. Surabaya: alIkhlas. 1983.

Daud, Ali Muhammad, Lembaga lembaga islam di Indonesia, Jakarta: Rjagrafindo Persada, 1994.

Departeman Agama RI, Al Qur'an dan Terjemahnya, al Hujurat

Hamka, Prinsip Kebijaksanaan Dakwah Islam. Jakarta: Pustaka Panjimas, 1990.

Hatta, Mohammad. Beberapa Fasal Ekonomi: Djalan ke Ekonomi dan Koperasi. Jakarta: Perpustakaan Perguruan Kementrian P.P. dan K. 1954.

Hidayat, Herman.Politik Lingkungan. Jakarta: Buku Obor Jikalahari. 2008

Koentjaraningrat, Kebudayaan Mentalitet dan Pembangunan. Jakarta: Gramedia, 1994.

Levang, Patrice. La terre D'en fase. Ayo ke Tanah Sabrang: Transmigrasi di Indonesia: La transmigration en l'Indonesie 1997). Jakarta: Kepustakaan Populer Gramedia. 2003.

Rukman Sardjadidjaja, Transmigrasi. Pembauran dan Integrasi Nasional. Jakarta: PT. Pustaka Sinar Harapan. 2004.

Sayyid Hussein Nasr, Menjelajahi Dunia Modern. Bandung: Mizan, 1993. Jurnal Dakwah Tabligh, Vol. 14,
No. 1, Juni 2013 : $101-113112$

Tabiligh Edisi XXVII / Juni 2013.

Sekretaris Umum DPD IMM Sumatera Utara. yang pernah menganalisa strategi dakwah Kuntowijoyo dalam masalah. Suara Muhammadiyah edisi November 1992.

Simak Didin Hafidhuddin dalam Adi Sasono, et all., Solusi Islam atas Problematika Umat (Ekonomi, Pendidikan dan Dakwah). Jakarta: Gema Insani Press. 1998

Sjamsu, Amral. Dari Kolonisasi ke Transmigrasi, 1905-1950. Jakarta: Penerbit Djambatan. 1960.

Soekanto Soerjono, Sosiologi Suatu Pengantar, Jakarta: Raja Grafindo Persada, 1990.

Sukirno, Sadono. Mikroekonomi Teori Pengantar. Jakarta: Gema Insani Press 2007.

Surjadi, Dakwah Islam Dengan Pembanguna Desa, Bandung: mandar Maju, 1998.

Sumber internet dan lain-lain:

Antara 20/3/2013. 'Cornelis Bantah Tolak Program Transmigrasi Perbatasan' | Tautan: http:// bit.ly/2qosHYw | Backup: http:// bit.ly/2qhbRj7 Mongabay.co.id 1/11/2012.

Bank Dunia, Publikasi o.t. Kerinci-Seblat Integrated Conservation and Development Project | http:// bit.ly/2r9iB21 | Backup: http:// bit.ly/2rsmRKC | Contoh dua publikasi yang terdapat di dalamnya: Proyek konservasi biodiversitas KNSP 2002 >http:// bit.ly/2r9z2uY | Proyek konservasi terintegrasi Kerinci- 
Seblat 2003 senilai USD 19,1juta kepada pemerintah Indonesia >http://bit.ly/2qmWLJe

BPS, Statististik Karet Indonesia. Katalog BPS 5504002. Jakarta: Badan Pusat 2002. Http://www.nakertrans.com, diakses pada tanggal 30 maret 2017.

http://www. eramuslim. com/ manhaj dakwah/ ma - aalim - fith thariiq/ ciri-ciri masyarakat islam. 9 Oktober 2017.

Lihat Tim Penyusun Kamus Pusat Pembinaan dan Pengembangan Bahasa, Kamus Besar Bahasa Indonesia. Jakarta: Balai Pustaka. 1990.

Maimunah, Siti n.y. 'Proposal Thesis'. Jakarta: Kesos UI, belum dipublikasikan

Ratusan Hektar Lahan Petani Dicaplok jadi Kebun Sawit di Banggai | Tautan: http://bit.ly/2ky7e0d | Backup:

Rencana Tata Ruang Wilayah (Rt Rw) Kabupaten Musi Rawas Berbasis Partisipatif Tahap 1. 2005 Badan Perencanaan Pembangunan Daerah Kabupaten Musi Rawas. 2005.

Ridwan, Karakteristik Dakwah Di Pedesaan, http://naifu.wordpress.com/ 2011/01/04/karakteristikdakwahdi-pedesaan-2/. 17 April 2017.

http;//Www.Artikelsiana.Com/2014/11/Sa luran-penyebaran-Islam-DiIndonesia-Cara.Html pada tangagal 25-3-17

Wawancara bapak Khoirunddin, Kepala Desa Sumber Makmur, 19 Maret 2017

Wikipedia. ensiklopedia bebas. https:// ms.wikipedia.org/wiki/Pertanian, diakses pada tanggal 30 maret 2017. 